\title{
Clinical evaluation of practolol in acute arrhythmias
}

\author{
Z. Rymaszewski, W. Popławska, J. Preibisz, and W. Januszewicz \\ From the Second Department of Medicine, Academy of Medicine, Warsaw, 59 Nowogrodzka \\ Street, Poland
}

Practolol was administered in 47 instances of acute arrhythmia, mainly of supraventricular origin. The drug was highly effective in 75 per cent of cases, including those with acute myocardial infarction. The therapeutic dose ranged from 5 to $180 \mathrm{mg}$. Despite administration of doses up to $500 \mathrm{mg}$, no serious side effects were noted.

The beta-adrenergic blocking agents are gaining increasingly wide application in the treatment of cardiac arrhythmias (Gibson and Sowton, 1969). Propranolol is the best known and, heretofore, the most commonly employed drug belonging to this group. However, the usefulness of propranolol in the management of acute disturbances of the cardiac rhythm is limited owing to its direct depressant action on the myocardium, to the blockade of the beta-adrenergic receptors of the bronchial musculature, and to the action on the peripheral circulation.

The purpose of the present study was the evaluation of the usefulness of one of the newer beta-adrenergic blocking agents, practolol, ${ }^{1}$ in the management of acute arrhythmias.

Practolol exerts selective action on myocardial beta-receptors (Bussmann, Rauh, and Krayenbuehl, 1970; Dunlop and Shanks, 1968; MacDonald and McNeill, 1968; Powles, Shinebourne, and Hamer, 1969; Sowton et al., 1968) and, in comparison with propranolol, has distinctly weaker direct depressant influence on the myocardium (Gibson, Balcon, and Sowton, 1968; Gibson and Sowton, 1969). These properties explain the increasing popularity of practolol as an antiarrhythmic drug (Gent, Davis, and McDonald, I970; Jewitt, Mercer, and Shillingford, 1969; Vohra, Dowling, and Sloman, 1970).

\section{Patients and methods}

Practolol was used in 47 instances of acute arrhythmia in 39 patients treated in the intensive

Received s April 197 I.

I ICI 50 172 Eraldin. coronary care unit (Table I). The underlying conditions were atherosclerotic ${ }^{\circ}$ heart disease (20 patients), acute myocardial infarction (I I patients), valvular heart disease (5 patients), and hyperthyroidism, scleroderma, and cor pulmonale ( $\mathrm{I}$ patient each). In 36 instances, practolol was the first antiarrhythmic drug tried, and in II instances other drugs or electrical cardioversion had been previously employed with no benefit. In 21 patients arrhythmia was associated with left ventricular failure. The drug was administered intravenously, the dose ranging from 5 to $500 \mathrm{mg}$, on average $66 \mathrm{mg}$, and the initial injection speed did not exceed $5 \mathrm{mg}$ a minute. The speed of injection depended upon the individual response of the patient and on the dose of the drug, and ranged from 2 to 60 minutes.

\section{Results}

The results are summarized in Table $I$. In the instances of successful termination of arrhyth-

TABLE I Evaluation of antiarrhythmic action of practolol

\begin{tabular}{|c|c|c|c|}
\hline & \multirow{2}{*}{$\begin{array}{l}\text { No. of } \\
\text { trials }\end{array}$} & \multicolumn{2}{|l|}{ Effect } \\
\hline & & Complete & Partial \\
\hline \multirow{5}{*}{$\begin{array}{l}\text { Paroxysmal supraven- } \\
\text { tricular tachycardia } \\
\text { Paroxysmal fibrillation } \\
\text { or flutter } \\
\text { Chronic atrial fibrilla- } \\
\text { tion with ventricular } \\
\text { rate }>\text { I } 40 \text { per min } \\
\text { Sinus tachycardia } \\
\text { Ventricular ectopic } \\
\text { beats }>\text { I / I0 }\end{array}$} & 18 & $15^{\star}$ & - \\
\hline & 19 & $5^{\star}$ & 7 \\
\hline & 4 & $3 t$ & - \\
\hline & & & \\
\hline & 4 & 2 & $\mathbf{I}$ \\
\hline Total & 47 & $27(58 \%)$ & $8(17 \%)$ \\
\hline
\end{tabular}

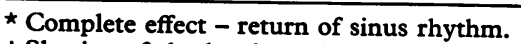

t Slowing of rhythm by at least 30 per minute. 
TABLE 2 Effect of practolol in arrhythmias associated with myocardial infarction

\begin{tabular}{|c|c|c|c|}
\hline & \multirow{2}{*}{$\begin{array}{l}\text { No. of } \\
\text { trials }\end{array}$} & \multicolumn{2}{|l|}{ Effect } \\
\hline & & Complete & Partial \\
\hline $\begin{array}{l}\text { Paroxysmal supraven- } \\
\text { tricular tachycardia } \\
\text { Paroxysmal atrial }\end{array}$ & 6 & 5 & 一 \\
\hline fibrillation of flutter & 7 & 2 & $\mathbf{I}$ \\
\hline Sinus tachycardia & I & I & - \\
\hline Total & 14 & 8 & $\mathbf{I}$ \\
\hline
\end{tabular}

mia with practolol, the dose of the drug ranged from 5 to $180 \mathrm{mg}$, on average $47 \mathrm{mg}$. In 12 instances, despite the large doses administered - on average $121 \mathrm{mg}$ - the antiarrhythmic effect of practolol was not seen.

Paroxysmal supraventricular tachycardia constituted the indication for treatment with practolol in 18 cases; an immediate return of sinus rhythm was obtained in 15 of these cases, including one patient who had been previously treated unsuccessfully with digitalis and quinidine and one who had undergone electrical cardioversion which had not terminated the arrhythmia.

Practolol was administered in 19 instances of paroxysmal atrial fibrillation or flutter and brought reversal to sinus rhythm in 5 of these cases. In 7, a partial success was expressed by obvious slowing of the ventricular rate, at least by 30 a minute, with resulting improvement of circulatory compensation, abatement of angina, and amelioration of peripheral perfusion.

Four patients were treated with practolol for chronic atrial fibrillation with rapid ventricular rates; two of these patients also had frequent digitalis-induced ventricular ectopic beats. Obvious slowing of the ventricular rate, at least by 30 a minute, was seen in 3 patients, and ventricular ectopic beats were abolished in both cases with extrasystoles. In the fourth case, administration of $20 \mathrm{mg}$ practolol resulted in slowing of the ventricular rate by 20 a minute, but in view of the fall of systolic blood pressure to $80 \mathrm{mmHg}$ the drug was discontinued.

In 2 instances of sinus tachycardia, administration of practolol resulted in a satisfactory slowing of the rhythm.

The drug was also used in 4 patients with frequent ventricular ectopic beats; in 2 of these patients the arrhythmia was abolished, and in I patient, an obvious reduction of frequency of the ectopic beats was obtained. It should be pointed out that in the 3 cases successfully treated with practolol, previous administration of lignocaine had been totally ineffective.

The antiarrhythmic action of practolol in myocardial infarction is presented in Table 2. Very good results of treatment were obtained in 5 out of 6 cases of paroxysmal supraventricular tachycardia, in I case of sinus tachycardia, and in 2 out of 7 cases of paroxysmal atrial fibrillation. Termination of arrhythmia was followed by disappearance or obvious diminution of pre-existent signs of left ventricular heart failure.

Despite repeated injections of large doses of practolol, no serious side effects were encountered in the whole group of 39 patients. A transient decrease of systolic blood pressure below $100 \mathrm{mmHg}$, without signs of shock, occurred in 3 instances. Sinus bradycardia with ventricular ectopic beats was seen in 2 patients after reversal to sinus rhythm. In I patient, in whom paroxysmal atrial flutter had been terminated with practolol, transient left bundle-branch block was seen for one hour afterwards.

\section{Discussion}

The results of the present study afford evidence of the potent antiarrhythmic effect of practolol, given intravenously. This effect was not obtained or was insignificant in only I2 $(25 \%)$ out of 47 instances of administration of practolol. In the initial period of the study, the doses employed did not exceed $60 \mathrm{mg}$. However, in the later stage, the good tolerance of the drug by the patients and the lack of significant side effects encouraged us to use larger doses which increased the efficacy of treatment.

It might be of interest to compare the results obtained in the two most common arrhythmias - paroxysmal supraventricular tachycardia and paroxysmal atrial fibrillation or flutter. Termination of arrhythmia was more frequently achieved in the former. Vohra et al., and Gent et al., using much smaller doses, did not obtain such a difference in results between the two types of arrhythmia, nor such a good overall efficacy of treatment.

Our results in cases of chronic atrial fibrillation and sinus tachycardia, where slowing of the ventricular rate and clinical improvement were obtained, are consistent with reports of other workers (Gent et al., I970; Jewitt et al., 1969; Vohra et al., I970). It seems that practolol could be particularly useful in patients with chronic atrial fibrillation and rapid ventricular rates during continuous digitalization. 
Administration of practolol in these cases promotes slowing of the ventricular rate, and clinical improvement and, by decreasing ventricular hyperexcitability, allows further digitalization.

Jewitt et al. reported beneficial action of practolol in cases of ventricular hyperexcitability 'refractory' to lignocaine (Jewitt et al., 1969). Our own results agree with this finding.

Our study indicates, in agreement with the results of others, that practolol is an efficacious and safe drug for the management of supraventricular arrhythmias supervening in the course of acute myocardial infarction (Jewitt et al., 1969; Vohra et al., 1970).

\section{Conclusions}

Practolol, a beta-adrenergic receptor blocking agent, is obviously effective in the management of paroxysmal arrhythmias. The present study is concerned mainly with supraventricular arrhythmias.

Practolol also slows the ventricular rate in cases of chronic atrial fibrillation with rapid ventricular rates and in sinus tachycardia. This effect makes the drug particularly useful for patients in whom ventricular hyperexcitability precludes digitalization.

For full achievement of the antiarrhythmic effect of practolol, the doses of the drug should be individually established in the range from a few to several hundred milligrams.

Untoward side effects, such as a transient fall in systolic blood pressure and disturbances of myocardial conduction, are rare and disappear when the drug is discontinued.

The above properties of practolol make this compound an efficacious and safe drug for the management of arrhythmias associated with acute myocardial infarction.
Samples of practolol (Eraldin) were kindly supplied by ICI, Ltd, England.

\section{References}

Bussmann, W. D., Rauh, M., and Krayenbuehl, H. P. (1970). Coronary and hemodynamic effects of myocardio-selective beta-receptor blockade by ICI 50172 in the closed-chest dog. American Heart fournal, 79, 347 .

Dunlop, D., and Shanks, R. G. (1968). Selective blockade of adrenoceptive beta-receptors in the heart. British fournal of Pharmacology and Chemotherapy, 32, 201.

Gent, G., Davis, T. C., and McDonald, A. (1970). Practolol in treatment of supraventricular cardiac dysrhythmias. British Medical fournal, 1, 533.

Gibson, D. G., Balcon, R., and Sowton, E. (1968). Clinical use of ICI 50172 as an antidysrhythmic agent in heart failure. British Medical fournal, 3, 161.

Gibson, D. G., and Sowton, E. (1969). The use of beta-adrenergic receptor blocking drugs in dysrhythmias. Progress in Cardiovascular Diseases, 12, 16.

Jewitt, D. E., Mercer, C. J., and Shillingford, J. P. (1969). Practolol in the treatment of cardiac dysrhythmias due to acute myocardial infarction. Lancet, 2, 227.

MacDonald, A. G., and McNeill, R. S. (I968). A comparison of the effect on airway resistance of a new beta blocking drug, ICI 50172 and propranolol. British fournal of Anaesthesia, 40, 508.

Powles, R., Shinebourne, E., and Hamer, J. (1969). Selective cardiac sympathetic blockade as an adjunct to bronchodilator therapy. Thorax, 24, 616.

Sowton, E., Balcon, R., Cross, D., and Frick, H. (1968). Haemodynamic effects of ICI 50172 in patients with ischaemic heart disease. British Medical fournal, $1,215$.

Vohra, J. K., Dowling, J. T., and Sloman, G. (1970). Practolol (ICI 50172), a beta-adrenergic receptor blocking agent, in the management of cardiac arrhythmias. Medical fournal of Australia, 2, 228.

Requests for reprints to Professor W. Januszewicz, Second Department of Medicine, Academy of Medicine, Warsaw, 59 Nowogrodzka Street, Poland. 